\title{
PENGEMBANGAN LEMBAR KERJA SISWA BERBASIS CONTEXTUAL TEACHING AND LEARNING PADA MATA PELAJARAN PERPAJAKAN KELAS X SEMESTER 1 SEKOLAH MENENGAH KEJURUAN
}

\author{
Ira Hasti Priyadi \\ Alumni FE Universitas Negeri Malang \\ aira_hesti@yahoo.co.id
}

\begin{abstract}
The purpose of this study is to develop the student worksheets based on taxation which developed in the form of student worksheets framework and consist of cover page, preface, table of contents, an introduction that contains standards of competence, basic competence, learning objectives, learning flow, keywords, supporting learning information, tasks, independent and groups employment as well as evaluation, glossary, and bibliography. Data collection used questionnaire. This study modified Borg and Gall (1983) model consist of analyzing the needs, developing product, validating, and revising. This result of this research is the availability of student worksheet based on contextual teaching and learning for taxation subject that have been validated.
\end{abstract}

\begin{abstract}
Abstrak: Tujuan dari penelitian ini adalah mengembangkan bahan ajar berupa Lembar Kerja Siswa (LKS) dan dikembangkan dengan kerangka LKS berupa, halaman sampul/ cover, kata pengantar, daftar isi, pendahuluan yang berisi standar kompetensi, kompetensi dasar, tujuan pembelajaran, alur pembelajaran, dan kata kunci serta pembelajaran yang memuat informasi pendukung, tugas-tugas dan langkah kerja mandiri serta kelompok, dan evaluasi, glosarium, serta daftar pustaka. Teknik pengumpulan data dalam penelitian ini menggunakan angket. Penelitian ini memodifikasi model pengembangan dari Borg and Gall (1983) meliputi analisis kebutuhan, pengembangan produk, validasi ahli, dan revisi. Hasil penelitian ini adalah tersedianya Lembar Kerja Siswa berbasis contextual teaching and learning pada mata pelajaran perpajakan yang valid atau layak digunakan.
\end{abstract}

Mutu pendidikan yang baik akan diikuti dengan hasil belajar siswa yang baik pula. Sekolah Menengah Kejuruan berusaha meningkatkan mutu pendidikan dengan cara meningkatkan hasil belajar siswa. Sekolah Menengah Kejuruan memiliki peran untuk menyiapkan siswa di dunia kerja, karena siswa lulusan Sekolah Menengah Kejuruan diharapkan mampu menghadapi era globalisasi yang membutuhkan Sumber Daya Manusia (SDM) yang berkualitas, mandiri, dan berdaya saing tinggi. 
Pendidikan yang baik dan berkualitas tentunya membutuhkan sistem pembelajaran dan guru yang berkualitas. Untuk menunjang kegiatan pembelajaran, sebaiknya guru menggunakan bahan ajar. Bahan ajar merupakan informasi, alat, dan teks yang diperlukan guru untuk perencanaan dan penelaahan implementasi pembelajaran. Bahan ajar adalah segala bentuk bahan yang digunakan untuk membantu guru/instruktur dalam melaksanakan kegiatan belajar mengajar. Bahan yang dimaksud bisa berupa bahan tertulis maupun bahan tidak tertulis. Bentuk bahan ajar banyak sekali yang dipakai dalam dunia pendidikan, salah satunya yaitu Lembar Kerja Siswa (LKS). LKS termasuk media cetak hasil pengembangan teknologi cetak yang berupa buku dan berisi materi visual (Arsyad, 2004). Menurut Surachman yang dikutip oleh Sumarni (2004 : 15-16), LKS merupakan jenis handout yang dimaksudkan untuk membantu siswa belajar secara terarah. Keberadaan LKS memberi pengaruh yang cukup besar dalam proses belajar mengajar, sehingga penyusunan LKS harus memenuhi berbagai persyaratan misalnya syarat didaktik, syarat konstruksi, dan syarat teknik.

Dalam hasil wawancara dengan guru mata pelajaran perpajakan yang dilakukan penulis di SMK Ardjuna 2 Malang pembelajaran di Sekolah Menengah Kejuruan tersebut belum menggunakan LKS ataupun bahan ajar lainnya seperti buku paket. Biasanya guru mata pelajaran perpajakan hanya memberikan handout ataupun catatan berupa rangkuman materi yang akan diajarkan. Peserta didik memperoleh materi hanya bersumber dari handout dan catatan yang telah diberikan dan dari penjelasan guru pada saat pembelajaran berlangsung hal ini karena belum ada LKS perpajakan yang dijual di pasaran dan buku paket ataupun LKS yang tersedia tidak mencangkup materi yang diajarkan belum memenuhi tujuan akademik yang ingin dicapai pada Rencana Pelaksanaan Pembelajaran (RPP) karena sebagian besar bahan ajar yang ada di pasaran seperti LKS ataupun buku paket tidak sesuai dengan kurikulum yang diterapkan di sekolah sehingga membuat siswa merasa kesulitan menyesuaikan dengan materi serta soal yang ada. Sebaiknya dalam mempelajari mata pelajaran perpajakan diperlukan cara dan metode belajar yang berbeda. Tidak semua materi dapat dipahami siswa dengan hanya membaca handout, buku ataupun mendengarkan penjelasan guru yang terbatas pada pembelajaran di sekolah. Mata pelajaran perpajakan bukan hanya pelajaran mengafal dan menghitung tata cara 
pengenaan penghasilan kena pajak, tetapi mata pelajaran perpajakan juga memerlukan banyak latihan dan keterampilan menghitung untuk dapat menyajikan Surat Pemberitahuan Pajak (SPT) Pajak Penghasilan Pasal 21 yang membutuhkan bahan ajar dengan latihan praktik pengisian langsung SPT dan bahan ajar yang cocok adalah Lembar Kerja Siswa (LKS) karena didalamnya mencangkup materi singkat serta latihan soal-soal.

Salah satu pelajaran yang kurang diminati siswa adalah mata pelajaran perpajakan. Mata pelajaran perpajakan merupakan mata pelajaran yang baru ditempuh oleh siswa Kelas X Sekolah Menengah Kejuruan, karena di tingkat Sekolah Menengah Pertama (SMP) mereka sama sekali belum mendapatkan mata pelajaran tersebut. Indikasi yang mudah dilihat adalah hasil belajar siswa yang cenderung kurang memuaskan, terutama pada perolehan nilai perpajakan yang berada di bawah memuaskan, terutama pada perolehan nilai perpajakan yang berada di bawah mata pelajaran lain.

Berdasarkan hasil kunjungan awal ke lokasi penelitian di Sekolah Menengah Kejuruan dari guru mata pelajaran perpajakan, diperoleh informasi bahwa mata pelajaran perpajakan merupakan mata pelajaran yang sulit dijelaskan secara verbal yang membutuhkan banyak latihan, karena berisi materi yang sulit dipahami siswa. Akan tetapi, metode pelajaran yang digunakan oleh para guru selama ini adalah metode konvensional dan dengan sedikit sekali variasi, sehingga dirasakan oleh kebanyakan sisa begitu monoton dan membosankan. Akibatnya siswa cenderung kurang aktif dalam pembelajaran, siswa merasa malas, tidur di dalam kelas, atau bahkan berada di luar kelas ketika pembelajaran sedang berlangsung.

Berdasarkan kegiatan pra survei yang dilakukan oleh peneliti di Sekolah Menengah Kejuruan, dalam silabus tercantum standar kompetensi perpajakan untuk kelas X SMK yaitu Menyiapkan Surat Pemberitahuan Pajak (SPT) PPh Pasal 21. Dalam standar kompetensi menyiapkan surat pemberitahuan pajak, mata pelajaran perpajakan membutuhkan suatu bahan ajar yang membutuhkan kegiatan praktik langsung yaitu praktik menyiapkan SPT, dari langkah awal memahami dasar perpajakan, kemmudian perhitungan pajak penghasilan, dan mengisi SPT PPh pasal 21 dan bahan ajar yang paling cocok untuk dikembangkan adalah Lembar Kerja 
Siswa karena dengan LKS, siswa akan mendapatkan banyak latihan soal yang langsung mengena di kehidupan nyata khusunya dalam pengisian SPT.

Suherli (2009) mengatakan bahwa dewasa ini masih terdapat sistem pembelajaran yang bersifat teoritis. Sebagian besar siswa belum dapat menangkap makna dari apa yang mereka peroleh dari pembelajaran untuk dapat diterapkan dalam kehidupan sehari-hari. Hal ini sesuai dengan kenyataan bahwa pada umumnya siswa tidak dapat menghubungkan apa yang telah mereka pelajari dengan cara pemanfaatan pengetahuan tersebut di kemudian hari (Gafur, 2003). Oleh sebab itu, dalam kondisi seperti ini guru harus mampu merancang sebuah pembelajaran yang benar-benar dapat membekali siswa baik pengetahuan secara teoritis maupun praktik. Dalam hal ini, guru harus pandai mencari dan menciptakan kondisi belajar yang memudahkan siswa dalam memahami, memaknai, dan menghubungkan materi pelajaran yang mereka pelajari. Selain itu, guru harus memberi bahan ajar yang mudah dipahami oleh anak didiknya. Salah satu alternatifnya yaitu guru dapat memilih model pembelajaran kontekstual dengan memberikan lembar kerja siswa kontekstual untuk menunjang pembelajaran.

Guru membantu peserta didik dalam belajar. Salah satu yang dilakukan oleh guru dalam proses mengajar adalah memberikan bahan ajar berupa LKS tentang materi yang akan dibahas agar dipelajari oleh peserta didik. Dengan cara ini diharapkan peserta didik mampu belajar secara mandiri. Johnson (dalam Trianto, 2007) mendefinisikan Contextual Teaching and Learning sebagai suatu proses belajar yang mengajak siswa melakukan tindakan mandiri yang melibatkan terkadang satu orang, biasanya satu kelompok. Tindakan mandiri ini dirancang untuk menghubungkan pengetahuan akademik dengan kehidupan sehari-hari sedemikian rupa untuk mencapai tujuan yang bermakna. Jadi dalam pembelajaran kontekstual dalam mata pelajaran perpajakan, guru memberikan lembar kerja siswa yang menghadirkan dunia nyata dan mendorong siswa membuat hubungan antara pengetahuan yang dimilikinya dengan penerapannya dalam kehidupan mereka sehari-hari. Tetapi dalam faktanya seringkali lembar kerja siswa yang dikembangkan menggunakan contoh-contoh perhitungan pajak yang tidak dekat dengan kehidupan peserta didik, misalnya berkutat pada perusahaan besar atau contoh wajib pajak yag jarang ditemui contoh kasusnya di tempat tinggal siswa. Siswa memperoleh 
pengetahuan dan keterampilannya dari konteks yang terbatas, sedikit demi sedikit, dan dari proses mengkontruksi sendiri, sebagai bekal untuk memecahkan masalah dalam kehidupannya sebagai anggota masyarakat.

\section{METODE}

Prosedur pengembangan dalam penelitian ini memodifikasi model pengembangan dari Borg and Gall (1983) yang disesuaikan dengan keadaan lapangan. Secara konseptual, pendekatan penelitian dan pengembangan mencakup langkah- langkah umum, sebagaimana diuraikan Borg \& Gall (1983:775). Dalam penelitian ini mengambil tujuh langkah dalam pengembangan Lembar Kerja Siswa Berbasis Contextual Teaching and Learning pada Mata Pelajaran Perpajakan, yaitu (1) analisis kebutuhan, (2) pengembangan produk, (3) validasi ahli, (4) revisi I, (5) uji coba lapangan terbatas, (6) revisi II, dan (7) produk akhir. Data yang diperoleh dari pengembangan LKS ini berupa data kuantitatif dan kualitatif. Data kuantitatif berupa skor angket penilaian dari validator uji coba lapangan terbatas, serta nilai peserta didik setelah mengerjakan LKS. Data kualitatif berupa tanggapan dan saran yang diberikan oleh validator ahli materi, ahli desain pembelajaran, guru, dan uji lapangan terbatas. Instrumen pengumpulan data yang digunakan dalam pengembangan LKS adalah angket dan produk LKS. Angket yang digunakan terdiri dari dua jenis, yaitu angket validasi dosen dan guru, dan angket penilaian siswa. Setiap angket memuat skor penilaian dan komentar atau saran terhadap LKS yang dikembangkan. Produk LKS juga di uji cobakan kepada peserta didik sehingga didapatkan nilai dari hasil mengerjakan LKS. Teknik analisis data yang digunakan dalam pengembangan LKS ini adalah teknik analisis deskriptif persentase, yaitu cara yang digunakan untuk mengubah data kuantitatif menjadi bentuk persentase dan kemudian diinterpretasikan dengan kalimat yang bersifat kualitatif. Analisis data sesuai dengan pendekatan ini, dimaksudkan bahwa setiap analisis disesuaikan dengan pendekatan yang digunakan, hanya sampai mengetahui persentase (\%) (Sudjana, 1990: 45). 


\section{HASIL DAN PEMBAHASAN}

Pengembangan Lembar Kerja Siswa ini dilakukan dalam beberapa tahapan. Tahap pertama adalah analisis kebutuhan. Kegiatan analisis kebutuhan yang dilakukan oleh peneliti selama kurang lebih satu bulan, peneliti mendapatkan informasi bahwa tujuan pembelajaran yang diharapkan dapat dicapai oleh peserta didik kelas X semester 1 Sekolah Menengah Kejuruan dalam mata pelajaran perpajakan yang didapatkan dari silabus serta rencana pelaksanaan pembelajaran dimana tujuan pembelajaran yang diharapkan yaitu mulai dari menjelaskan pengertian pajak, unsur-unsur pajak dengan benar, kemudian menjelaskan fungsi pajak, menjelaskan pajak penghasilan, menghitung serta mengisi surat pemberitahuan pajak penghasilan bagi pegawai tetap, penerima pensiun, pegawai harian, mingguan, satuan, dan borongan, serta pajak penghasilan bagi dokter, dan profesi lainnya.

Tahap kedua adalah pengembangan produk. Di dalam pengembangan LKS, terdapat sejumlah prinsip yang perlu diperhatikan. LKS harus dikembangkan atas dasar hasil analisis kebutuhan dan kondisi. Berdasarkan hasil analisis yang telah didapat, LKS pembelajaran berbasis contextual teaching and learning kelas $\mathrm{X}$ Akuntansi dikembangkan dengan tujuan untuk menunjang pembelajaran perpajakan karena LKS tersebut dapat membantu peserta didik dalam pembelajaran perpajakan apabila dikaitkan dengan kehidupan nyata yang berkembang di lingkungan kehidupan peserta didik. Pengembangan LKS, perlu diketahui dengan pasti materi belajar apa saja yang perlu disusun dengan mengacu pada silabus selanjutnya dikembangkan desain LKS yang dinilai paling sesuai dengan berbagai data dan informasi yang diperoleh dari analisis kebutuhan dan kondisi di atas. LKS yang peneliti kembangkan mempunyai keunggulan yaitu desain yang menarik dengan tampilan warna yang beragam, kelengkapan materi yang memungkinkan peserta didik tidak perlu menggunakan bahan ajar lain sebagai sumber belajarnya, ilustrasi yang dekat pada dunia siswa, contoh soal bervariasi yang menghadirkan jenis soal sederhana sampai kompleks, serta penilaian karakter di akhir evaluasi per babnya. Menurut Direktorat Pembinaan Sekolah Menengah Kejuruan (2008: 10) proses penyusunan LKS terdiri dari tiga tahapan pokok, yaitu (1) menetapkan strategi pembelajaran yang sesuai, (2) memproduksi fisik LKS, dan (3) mengembangkan 
perangkat penilaian. Tampilan cover, kata pengantar, daftar isi, pendahuluan, pembelajaran, evaluasi, karakter yang diamati, glosarium dan daftar pustaka yang dihasilkan adalah sebagaimana gambar berikut:

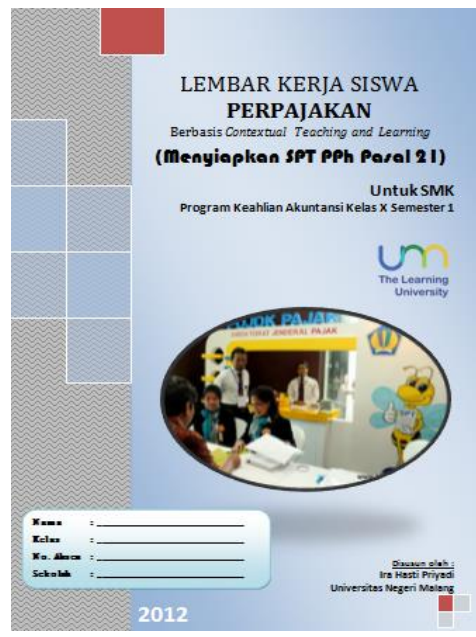

Gambar 1. Cover

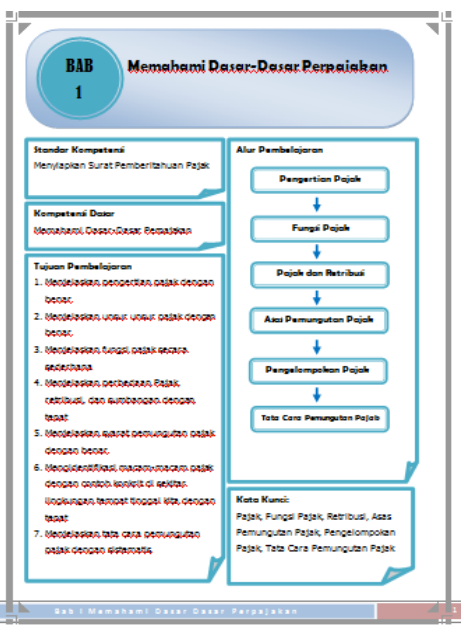

Gambar 4. Pendahuluan

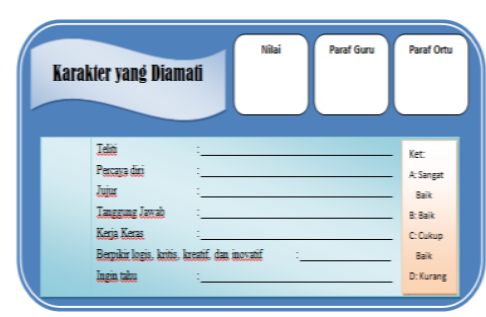

Gambar 7. Karakter yang diamati

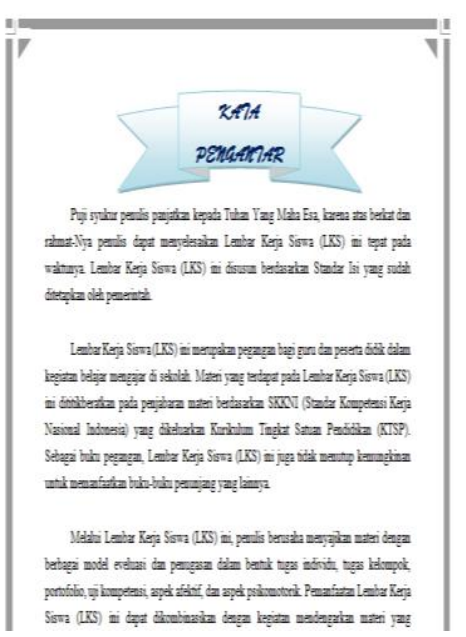

Gambar 2. Kata pengantar

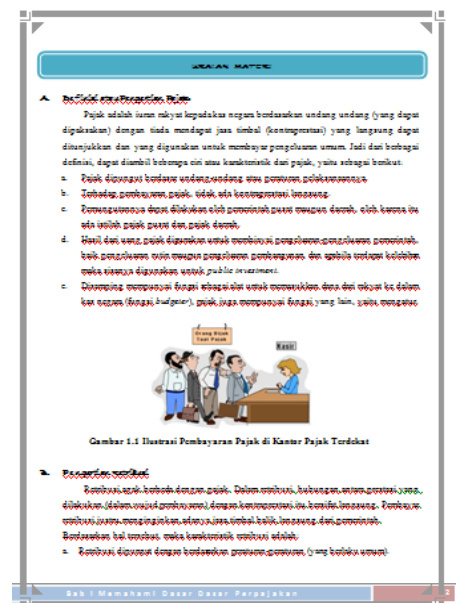

Gambar 5. Pembelajaran

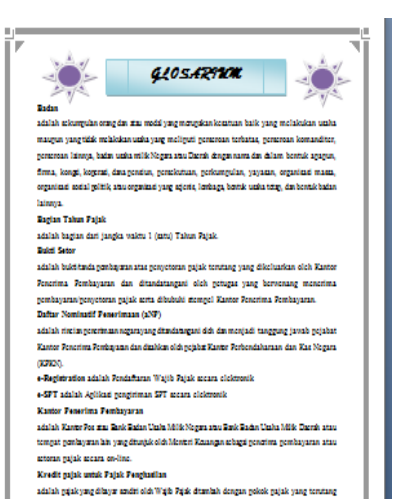

Gambar 8. Glosarium

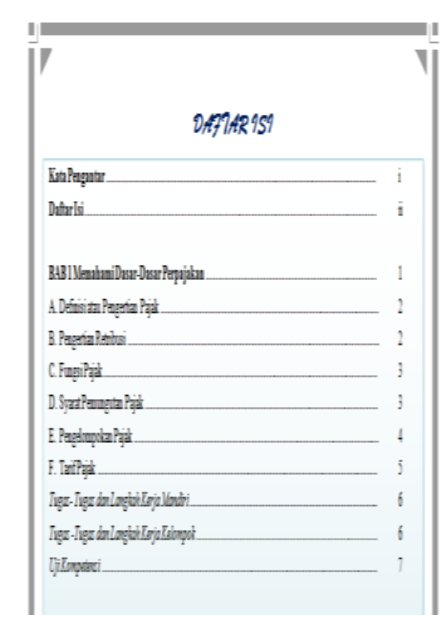

Gambar 3. Daftar isi

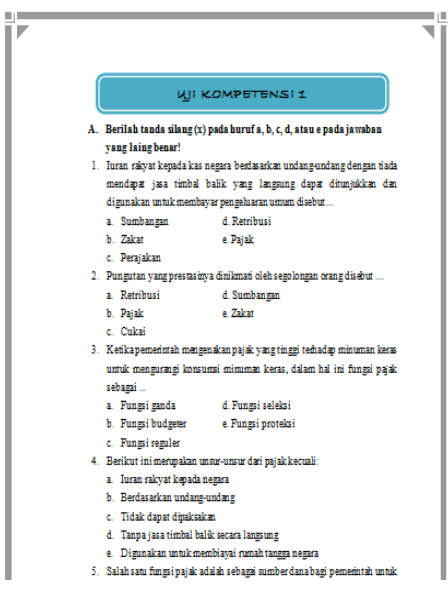

Gambar 6. Evaluasi

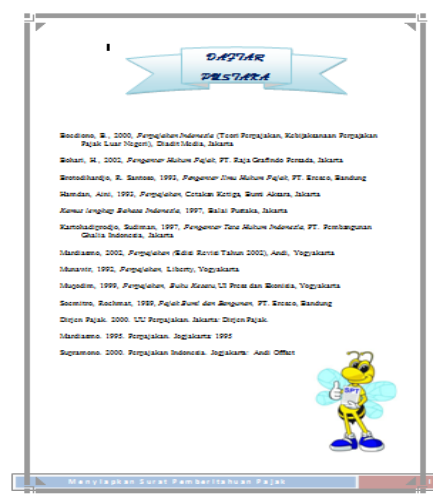

Gambar 9. Daftar pustaka 
Tahap ketiga adalah validasi ahli. Hasil validasi ahli dapat ditunjukkan pada tabel 1 .

Tabel 1. Analisis Keseluruhan Validasi Ahli Materi, Ahli Desain Pembelajaran, dan Guru

\begin{tabular}{|c|l|c|c|c|c|c|}
\hline No & \multicolumn{1}{|c|}{$\begin{array}{c}\text { Aspek yang } \\
\text { dinilai }\end{array}$} & $\begin{array}{c}\text { Ahli } \\
\text { Materi }\end{array}$ & $\begin{array}{c}\text { Ahli } \\
\text { Desain } \\
\text { Pembelajaran }\end{array}$ & Guru & Rerata & $\begin{array}{c}\text { Kriteria } \\
\text { Kevalidan }\end{array}$ \\
\hline 1. & Cover & 91,67 & 100 & 91,67 & 94,67 & Valid \\
\hline 2. & Kata Pengantar & 100 & 100 & 100 & 100 & Valid \\
\hline 3. & Daftar Isi & 100 & 100 & 100 & 100 & Valid \\
\hline 4. & $\begin{array}{l}\text { Standar } \\
\text { Kompetensi }\end{array}$ & 100 & 100 & 100 & 100 & Valid \\
\hline 5. & Kompetensi Dasar & 100 & 100 & 100 & 100 & Valid \\
\hline 6. & $\begin{array}{l}\text { Tujuan } \\
\text { Pembelajaran }\end{array}$ & 100 & 100 & 100 & 100 & Valid \\
\hline 7. & Alur Pembelajaran & 100 & 100 & 100 & 100 & Valid \\
\hline 8. & Kata Kunci & 100 & 100 & 100 & 100 & Valid \\
\hline 9. & $\begin{array}{l}\text { Informasi } \\
\text { Pendukung/ Uraian } \\
\text { Materi }\end{array}$ & 95 & 100 & 90 & 95 & Valid \\
\hline 10. & $\begin{array}{l}\text { Tugas-Tugas dan } \\
\text { LK Man. }\end{array}$ & 100 & 100 & 100 & 100 & Valid \\
\hline 11. & $\begin{array}{l}\text { Tugas-Tugas dan } \\
\text { LK Kel. }\end{array}$ & 100 & 100 & 100 & 100 & Valid \\
\hline 12. & Uji Kompetensi & 100 & 100 & 75 & 91,67 & Valid \\
\hline 13. & Karakter & 100 & 100 & 100 & 100 & Valid \\
\hline 14. & Glosarium & 100 & 100 & 100 & 100 & Valid \\
\hline 15. & Daftar Pustaka & 100 & 100 & 75 & 91,67 & Valid \\
\hline & $\quad \sum$ & 99,11 & 100 & 95,44 & 98,19 & Valid \\
\hline
\end{tabular}

Data kualitatif diperoleh dari hasil komentar dan saran dari validator ahli. Komentar dan saran tersebut akan menjadi pertimbangan revisi produk untuk perbaikan LKS. Pada tabel 2, tabel 3, dan tabel 4 berikut disajikan komentar dan saran dari validator ahli.

Tabel 2. Kritik dan Saran serta Pendapat Secara Umum dari Ahli Materi No Kritik dan Saran serta Pendapat secara umum

\section{Kritik dan Saran}

1 Judul LKS Perpajakan diganti menjadi LKS PPh Pasal 21

2 Judul Bab di LKS disesuaikan dengan materi

3 Perlu ada penambahan materi di Bab 4 yaitu SPT Masa

\section{Pendapat Secara Umum}

Secara keseluruhan LKS ini sudah bagus, materinya juga sudah memadai lengkap hanya saja perlu memperbaiki cover dan penambahan contoh formulir SPT Masa. 
Tabel 3. Kritik dan Saran serta Pendapat secara Umum dari Ahli Desain Pembelajaran

\begin{tabular}{l}
\hline No Kritik dan Saran serta Pendapat secara umum \\
\hline $\begin{array}{l}\text { Kritik dan Saran } \\
1 \quad \begin{array}{l}\text { Penyusunan LKS ditambahkan kata telah sesuai di silabus pada "kata } \\
\text { pengantar" }\end{array} \\
\mathbf{2} \text { Gambar pada halaman 5, 16, dan } 64 \text { sebelum LKS di revisi diganti } \\
\text { dengan gambar yang lebih bermakna }\end{array}$ \\
$\begin{array}{l}\text { Pendapat Secara Umum } \\
\text { Secara keseluruhan LKS ini sudah bagus, gambarnya juga sudah menarik, } \\
\text { namun sebaiknya LKS diberi gambar yang lebih bermakna dan penyusunannya } \\
\text { harus sesuai silabus, oleh karena itu perlu ditambahkan statement di kata } \\
\text { pengantar. }\end{array}$ \\
\hline
\end{tabular}

Tabel 4. Kritik dan Saran Serta Pendapat secara Umum dari Guru

\begin{tabular}{|c|c|}
\hline \multicolumn{2}{|r|}{ No Kritik dan Saran serta Pendapat secara umum } \\
\hline \multicolumn{2}{|c|}{ Kritik dan Saran } \\
\hline 1 & $\begin{array}{l}\text { Gambar cover diganti dengan gambar di ruang kantor KPP dengan } \\
\text { suasana orang sedang antri menyetor SPT }\end{array}$ \\
\hline 2 & $\begin{array}{l}\text { Materi NPWP sebaiknya diberi contoh kartu NPWP bagian depan dan } \\
\text { belakang }\end{array}$ \\
\hline 3 & Beri contoh tentang urutan perhitungan sampai dengan pengisian SPT \\
\hline 4 & $\begin{array}{l}\text { Tugas kelompok ditambah materi (beri bukti pembayaran pajak yang } \\
\text { cukup) }\end{array}$ \\
\hline 5 & $\begin{array}{l}\text { Contoh soal pada uji kompetensi perlu ditambahkan status anggota } \\
\text { keluarga }\end{array}$ \\
\hline 6 & Pemberian soal uji kompetensi memuat tiga perintah soal \\
\hline 7 & $\begin{array}{l}\text { Daftar pustaka dengan buku yang ditulis oleh mardiasmo disesuaikan } \\
\text { dengan tahun terbitan yang terbaru }\end{array}$ \\
\hline \multicolumn{2}{|r|}{ Pendapat Secara Umum } \\
\hline & $\begin{array}{l}\text { a keseluruhan LKS ini sudah bagus, tetapi perlu direvisi sesuai yang } \\
\text { urkan }\end{array}$ \\
\hline
\end{tabular}

Tahap keempat adalah revisi I. Revisi ahli materi dilakukan untuk memperbaiki LKS dan penyempurnaan LKS. Revisi tersebut meliputi (1) judul LKS yang berjudul Lembar Kerja Siswa Perpajakan diganti dengan Lembar Kerja Siswa PPh Pasal 21 karena LKS lebih membahas PPh Pasal 21 secara khusus dan apabila tetap mempertahankan judul awal maka dalam LKS harus berisi pajak secara utuh, mulai dari pengertian sampai pembahasan pajak pasal lainnya, misalnya 21, 22, 26, dan sebagainya, (2) judul Bab di LKS tidak harus sama persis dengan kata-kata pada kompetensi dasar namun sebaiknya disesuaikan dengan materi, misalnya pada Bab 1, pada awalnya judul Bab sama dengan kompetensi dasarnya yaitu memahami dasar- 
dasar perpajakan, namun sebaiknya diganti dengan kalimat yang mudah atau sederhana yaitu dasar-dasar perpajakan, begitu juga dengan bab yang lain, (3) Materi dalam LKS perlu ditambahkan contoh formulir SPT Masa karena ada dua jenis SPT yang dibahasa di dalam materi, yaitu SPT Masa dan SPT Tahunan, maka harus dijelaskan juga contoh SPT Masa.

Revisi ahli desain pembelajaran dilakukan untuk memperbaiki LKS dan penyempurnaan LKS. Revisi tersebut meliputi (1) penyusunan Lembar kerja Siswa ini, harus sesuai dengan silabus. Oleh karena itu, perlu ditambahkan statement yang menyatakan bahwa penyusunan LKS sudah sesuai dengan silabus yang berlaku dan (2) gambar yang ada pada kolom sebaiknya diganti dengan gambar yang lebih bermakna karena gambar harus memuat maksud yang jelas dalam penyusunan LKS tidak asal menarik saja.

Revisi guru mata pelajaran perpajakan dilakukan untuk memperbaiki LKS dan penyempurnaan LKS. Revisi tersebut meliputi (1) gambar cover sebaiknya diganti dengan suasana orang sedang antre di ruang KPP karena standar kompetensi yang diinginkan adalah menyiapkan SPT PPh Pasal 21 oleh karena itu, lebih baik apabila gambar juga disesuaikan dengan standar kompetensi, (2) tugas kelompok pada Bab I ditambah dengan bukti pembayaran pajak yang cukup sehingga siswa bisa menganalisis dan mengelompokkannya berdasarkan materi pengelompokan pajak sebelumnya karena di tugas kelompok hanya ada dua gambar saja sebagai tugas. Dan untuk bab 2, direvisi dengan menambah soal kerja kelompok menjadi 4 butir gambar yang dianalisis, dari gambar awal revisi yang hanya berisi dua bukti, (3) pada Bab III materi sebaiknya ditambah dengan contoh kartu NPWP yang tampak bagian depan dan belakang, (4) revisi Uji Kompetensi juga harus di revisi yaitu pada uji kompetensi terakhir, soal direvisi dari awalnya yang tidak menyebutkan status (dalam keluarga) diisi lengkap (nama istri, nama anak, tempat tanggal lahir, hubungan, dan pekerjaan) sehingga siswa mudah dalam pengisian PTKP nya. Dan penulisan gelar diperbaiki dari Dr. Menjadi dr. Kemudian dibuatkan perintah soal menjadi tiga yang pada awalnya hanya satu, (5) daftar Pustaka dirujuk dari sumber terbaru, misalnya buku mardiasmo, karena sudah ada yang terbaru maka tahun diganti 2011. 
Tahap berikutnya adalah uji lapangan terbatas. Pada uji coba ini, peneliti mengambil sampel untuk validasi di Sekolah Menengah Kejuruan Ardjuna 2 Malang sebanyak 12 siswa yaitu kelas X Akuntansi yang dilaksanakan tanggal 12 November 2012. Berikut ini disajikan hasil data dari tanggapan uji coba lapangan mengenai produk LKS berbasis contextual teaching and learning yang dikelompokkan berdasarkan data kuantitatif dan data kualitatif.

Data kuantitatif diperoleh dari angket validasi uji coba lapangan terbatas terhadap LKS yang dikembangkan. Rangkuman hasil data seperti pada tabel 5 berikut.

Tabel 5. Analisis Uji Coba Lapangan Terbatas

\begin{tabular}{|c|l|c|c|}
\hline No & Komponen yang dinilai & $\begin{array}{c}\text { Persentase } \\
\mathbf{\%}\end{array}$ & Kriteria Kevalidan \\
\hline 1 & Penyajian & 91 & Valid/ Digunakan \\
\hline 2 & Bahasa & 87,67 & Valid/ Digunakan \\
\hline 3 & Gambar dan Ilustrasi & 94,5 & Valid/ Digunakan \\
\hline 4 & Materi & 94,67 & Valid/ Digunakan \\
\hline & Rata-Rata & 91,96 & Valid/ Digunakan \\
\hline
\end{tabular}

Berdasarkan tabel 5, dapat dilihat hasil analisis terhadap angket validasi oleh uji coba lapangan terbatas dari aspek penyajian diperoleh kriteria valid/ digunakan dengan persentase sebesar $91 \%$, aspek bahasa diperoleh kriteria valid/ digunakan dengan persentase sebesar $81,67 \%$, gambar dan ilustrasi diperoleh kriteria valid/ digunakan dengan persentase 94,67\%, dan pek materi diperoleh kriteria valid/ diginakan dengan persentase sebesar 91,96\%. Hasil validasi LKS dari uji coba lapangan terbatas diperoleh rata-rata persentase sebesar $91,96 \%$ dan disimpulkan bahwa LKS yang telah dikembangkan oleh peneliti sudah cukup valid dan layak digunakan dalam proses pembelajaran perpajakan sekolah menengah kejuruan dari segi pengguna LKS yang disajikan.

Data kualitatif diperoleh dari angket validasi uji coba lapangan terbatas terhadap LKS yang dikembangkan. Hasil validasi tersebut berupa komentar, pendapat, dan saran yang dijadikan dasar revisi produk II untuk penyempurnaan LKS. Meskipun berdasarkan data kuantitatif LKS telah dinyatakan valid/ layak digunakan, namun demikian untuk menindaklanjuti pendapat dan saran dari pengguna, maka LKS tetap direvisi. Hasil validasi uji coba lapangan terbatas dapat dilihat pada table 6 . 
Tabel 6. Kritik dan Saran serta Pendapat secara Umum dari Uji Coba Lapangan Terbatas

No Kritik dan Saran serta Pendapat secara umum

Kritik dan Saran

1 Lembar Kerja Siswa terlalu tebal sehingga dapat mengurangi minat baca

2 Penulisan ejaan kata dalam LKS ada beberapa yang salah ketik.

\section{Pendapat Secara Umum}

1. Materi yang disajikan di LKS sudah sangat bagus karena penataan dengan gambar full color membuat tidak bosan dalam membaca

2. Bahasa yang digunakan sederhana rumit dan mudah dimengerti

3. Menambah wawasan baru tentang perpajakan

Dalam uji coba lapangan terbatas, siswa mengerjakan LKS yang telah diberikan, sehingga setelah siswa mengerjakan LKS dapat diketahui nilanya. Data rangkuman nilai siswa dapat dilihat pada tabel 7 .

Tabel 7. Data Hasil Belajar Siswa

\begin{tabular}{cccl}
\hline Kategori & Nilai & $\sum$ Siswa & \multicolumn{1}{c}{ Keterangan } \\
\hline A & $\geq 86$ & 5 & $\begin{array}{l}\text { Siswa telah menyelesaikan soal LKS dengan } \\
\text { baik }\end{array}$ \\
B & $70-85$ & 6 & $\begin{array}{l}\text { Siwa telah menyelesaikan soal LKS dengan } \\
\text { baik, tetapi sebaiknya mempelajari kembali } \\
\text { LKS terutama bagian yang siswa anggap } \\
\text { belum dikuasai }\end{array}$ \\
C & $\leq 69$ & 1 & $\begin{array}{l}\text { Siswa belum menyelesaikan LKS dengan baik } \\
\text { dan harus mengulangi kegiatan belajar di } \\
\text { dalam LKS }\end{array}$ \\
\hline
\end{tabular}

Tahap berikutnya adalah revisi II. Revisi produk II dilakukan berdasarkan data yang diperoleh dari hasil uji lapangan terbatas untuk memperbaiki dan menyempurnakan LKS berbasis contextual teaching and learning pada mata pelajaran perpajakan sekolah menengah kejuruan ditinjau dari pengguna. Revisi tersebut meliputi (1) lembar kerja siswa terlalu tebal sehingga dapat mengurangi minat siswa untuk membaca. Hal ini perlu direvisi karena dapat mempengaruhi minat baca siswa. (2) penulisan ejaan kata dalam LKS ada beberapa yang salah ketik, hal ini perlu direvisi untuk lebih menyempurnaan LKS.

Tahap terakhir yaitu produk akhir. Setelah sudah tidak ada revisi lagi, maka produk akhir yang dihasilkan berupa LKS berbasis contextual teaching and learning pada mata pelajaran perpajakan sekolah menengah kejuruan kelas $\mathrm{X}$ semester 1 dengan pokok bahasan menyiapkan surat pemberitahuan pajak. Dari seluruh data 
yang diperoleh dari validasi ahli materi, ahli desain pembelajaran, guru mata pelajaran, dan uji coba lapangan terbatas dapat dilihat pada tabel 8 .

Tabel 8. Analisis Keseluruhan Validasi

\begin{tabular}{|c|l|c|l|}
\hline No & \multicolumn{1}{|c|}{ Komponen yang dinilai } & $\begin{array}{c}\text { Persentase } \\
\mathbf{\%}\end{array}$ & \multicolumn{1}{|c|}{ Kriteria Kevalidan } \\
\hline 1 & Rata-rata validasi ahli materi & 99,11 & Valid/ Digunakan \\
\hline 2 & $\begin{array}{l}\text { Rata-rata validasi ahli desain } \\
\text { pembelajaran }\end{array}$ & 100 & Valid/ Digunakan \\
\hline 3 & Rata-rata validasi guru & 95,44 & Valid/ Digunakan \\
\hline 4 & $\begin{array}{l}\text { Rata-rata validasi uji coba lapangan } \\
\text { terbatas }\end{array}$ & 91,96 & Valid/ Digunakan \\
\hline & Rata-rata keseluruhan validasi & 96,63 & Valid/ Digunakan \\
\hline
\end{tabular}

Produk akhir penelitian pengembangan ini berupa LKS berbasis contextual teaching and learning pada mata pelajaran perpajakan sekolah menengah kejuruan yang digunakan sebagai bahan ajar pada mata pelajaran perpajakan dengan pokok bahasan menyiapkan surat pemberitahuan pajak, setelah melalui tahap validasi yang melibatkan ahli materi, ahli desain pembelajaran, guru mata pelajaran, dan uji coba lapangan terbatas, dilakukan analisis terhadap data hasil validasi tersebut. Data kualitatif validasi digunakan sebagai pertimbangan melakukan beberapa revisi untuk memaksimalkan penggunaan LKS, sedangkan data kuantitatif digunakan sebagai dasar untuk menentukan kevalidan/ kelayakan LKS berbasis contextual teaching and learning pada mata pelajaran perpajakan sekolah menengah kejuruan sehingga didapatkan bahan ajar yang layak dan memenuhi kriteria.

Data kualitatif dan kuantitatif dibuktikan dengan hasil perhitungan dari ahli materi didapatkan kriteria valid/ digunakan dengan skor persentase sebesar 96,63\%. Sebagian besar aspek yang dinilai dalam LKS ini menunjukkan kriteria valid, sehingga tidak perlu direvisi dan LKS ini dapat dikatakan layak untuk digunakan dalam pembelajaran. Akan tetapi untuk kesempurnaan dalam pengembangan LKS maka berdasarkan komentar dan saran yang diberikan ahli materi dilakukan revisi yaitu mengenai judul LKS, judul bab, dan penambahan materi. Aspek yang dinilai dalam LKS ini menunjukkan sebagian besar menunjukkan kriteria valid dan tidak perlu direvisi. Akan tetapi sesuai dengan saran dan komentar yang telah diberikan oleh validator, maka harus tetap direvisi demi kesempurnaan LKS yaitu dengan menyempurnakan daftar pustaka, dan mengganti gambar dengan gambar yang lebih 
bermakna. Validasi dari guru mata pelajaran diperoleh skor persentase 95,44\% dengan semua aspek memperoleh kriteria valid. Meskipun memperoleh kriteria valid akan tetapi berdasarkan saran dan komentar yang diberikan, maka LKS harus direvisi dengan mengganti gambar cover, menambah materi yang belum ada, menambah contoh perhitungan ataupun contoh soal sampai dengan melengkapi daftar pustaka sehingga LKS dapat digunakan dalam pembelajaran. Uji coba lapangan terbatas didapatkan kriteria cukup/ valid digunakan dengan skor persentase sebesar 91,96\%. Saran dan komentar yang diperoleh dari hasil uji coba lapangan terbatas yaitu agar tampilan LKS lebih tipis dan memperbaiki tulisan yang salah ketik

Berdasarkan tabel 8 diperoleh dari ahli materi dengan nilai rata-rata persentase sebesar 99,11\%, ahli desain pembelajaran diperoleh nilai rata-rata persentase sebesar $100 \%$, validasi dari guru diperoleh nilai rata-rata persentase sebesar 95,44\%. dan uji coba lapangan terbatas diperoleh nilai rata-rata persentase sebesar 91,96\%, sehingga diperoleh nilai rata-rata persentase keseluruhan sebesar 96,63 \% dan disimpulkan bahwa LKS berbasis contextual teaching and learning pada mata pelajaran perpajakan sekolah menengah kejuruan valid atau layak digunakan sebagai bahan ajar.

\section{SIMPULAN}

LKS pembelajaran berbasis contextual teaching and learning pada mata pelajaran perpajakan sekolah menengah kejuruan jurusan akuntansi kelas X semester 1 dikembangkan dengan memberikan contoh kasus dan tugas dalam kehidupan nyata yang dapat membantu siswa dalam pembelajaran akuntansi. Pengembangan LKS disusun dengan mengggunakan kerangka halaman sampul, kata pengantar, daftar isi, pendahuluan, pembelajaran, evaluasi, karakter yang diamati, glosarium, dan daftar pustaka (Direktorat Pembinaan Sekolah Menengah Kejuruan, 2008: 33). Hasil akhir pengembangan LKS ini berupa LKS berbasis contextual teaching and learning pada mata pelajaran perpajakan yang digunakan untuk menyajikan SPT Tahunan PPh Pasal 21. Setelah melalui tahap validasi yang melibatkan ahli materi, ahli desain pembelajaran, guru mata pelajaran, dan uji coba lapangan terbatas, dilakukan analisis terhadap hasil validasi tersebut. Data kualitatif validasi digunakan sebagai dasar 
untuk menentukan kevalidan/ kelayak LKS. Hal ini dibuktikan dengan hasil perhitungan dari ahli materi didapatkan kriteria valid/ digunakan dengan skor persentase sebesar 99,11\%. Ahli desain pembelajaran didapatkan kriteria valid/ digunakan dengan skor $100 \%$. Guru mata pelajaran didapatkan kriteria valid/ digunakan dengan skor $95,44 \%$ dan dari uji coba lapangan terbatas didapatkan kriteria valid/ digunakan dengan skor persentase sebesar 91,96\%. Sehingga diperoleh nilai rata-rata persentase keseluruhan sebesar 96,63\% dan disimpulkan bahwa LKS perpajakan berbasis contextual teaching and learning sekolah menengah kejuruan valid atau layak sebagai bahan ajar.

Adapun keterbatasan dalam penelitian pengembangan LKS berbasis contextual teaching and learning pada mata pelajaran perpajakan yang dikembangkan, yaitu (1) kelas uji coba lapangan terbatas belum menggunakan kelas kontrol, sehingga tidak diketahui efektifitas penggunaan LKS yang dikembangkan untuk mengetahui peningkatan hasil belajar pada kelas yang menggunakan LKS dan kelas yang tidak menggunakan LKS dan (2) model pengembangan bisa menggunakan model pengembangan dari pakar lain yang lebih lengkap.

\section{DAFTAR RUJUKAN}

Arsyad, Azhar. 2004. Jenis-Jenis Bahan Ajar. Jakarta: PT Bumi Aksara.

Borg, W.L., and Gall, M.D. 1983. Educational Research: an introduction. London: Longman, Inc

Gafur. 2003. Pembelajaran yang Efektif. Jakarta: Raja Grafindo Persada.

Sumarni. 2004. Pengembangan Bahan Ajar. Jakarta: PT Elek Media Komputindo.

Suherli, 2009. Model Pembelajaran Kontekstual (Contextual Teaching and Learning.(online),(http://irfazak.blogspot.com/2009/04/model-pembelajarankontekstual.html), diakses tanggal 9 Oktober 2012.

Trianto. 2007. Mendesain Pembelajaran Kontekstual (Contextual Teaching and Learning) Di Kelas. Surabaya: Cerdas Pustaka Publisher. 
